\title{
HARTA SEPENCARIAN/ASET PERKAHWINAN BAGI PEMBUBARAN PERKAHWINAN DI BAWAH SEKSYEN 51 AKTA MEMBAHARUI UNDANG- UNDANG (PERKAHWINAN DAN PERCERAIAN) 1976 SERTA AKTA UNDANG-UNDANG KELUARGA ISLAM (WILAYAH-WILAYAH PERSEKUTUAN) 1984
}

\section{Matrimonial Asset for Couple to the Dissolution of Marriage Under Section 51 of The Law Refoem Act (Marriage and Divorce) Act 1976 and Islamic Family Law (Federal Teritories) 1984}

\author{
Norazlina Abdul Aziz \\ Senior Lecturer, Faculty of Law, \\ Universiti Teknologi Mara \\ 40450 Shah Alam Selangor \\ nora_aaz@yahoo.com \\ Irini Ibrahim \\ Senior Lecturer, Faculty of Law, \\ Universiti Teknologi Mara \\ 40450 Shah Alam Selangor \\ irini_ibrahim@yahoo.com \\ Mohd Norhusairi Mat Hussin \\ Senior Lecturer, Department of Shariah and Law \\ Academy of Islamic Studies \\ University of Malaya, 50603 Kuala Lumpur \\ husairi@um.edu.my
}

\begin{abstract}
The marriage between non-Muslim couple where one spouse later converted to Muslim results in the dissolution of marriage under the Shariah law. However as they had gotten married under the
\end{abstract}


Law Reform (Marriage and Divorce) Act 1976 (LRA), thus the dissolution of marriage shall fall under the jurisdiction of section 51 of the Act. This writing discusses the issue attach to such dissolution of marriage with specific reference to the division of matrimonial asset. This study adopts qualitative approach that utilised doctrinal study and semi-structured interview with experts of this area. The Islamic Family Law (Federal Teritories) 1984 was analysed this issue within the context of Shariah law in Malaysia. The summarized of findings to this study uncovered that both Civil and Shariah Court consider similar principles in division of matrimonial asset for couple to the dissolution of marriage under section 51 of LRA.

Keywords: matrimonial asset, Shariah Law, Civil Law, dissolution of marriage

\section{PENDAHULUAN}

E.N. Taylor di dalam mukadimmah makalahnya mengatakan bahawa masyarakat Melayu tempatan tidak mematuhi keseluruhan undang-undang Islam sebagaimana yang dihuraikan oleh ahli fuqaha berbangsa Arab. Malahan katanya lagi mahkamah di sini memakai undang-undang Islam bercampur baur dengan adat Melayu lama. Analisis yang mendalam tentang kes-kes yang dilaporkan oleh E.N. Taylor jelas menunjukkan amalan memakai undangundang Islam di samping adat Melayu adalah meluas di semua negeri di Tanah Melayu.

Selaras dengan itu dapatlah dikatakan bahawa undang-undang di Malaysia ini adalah bercampur di antara undang-undang adat, Undang-Undang Islam dan Undang-undang Inggeris. Dalam membincangkan prinsip-prinsip yang digunakan oleh hakim-hakim di Malaysia ketika menyelesaikan soal-soal harta perkahwinan kita akan lihat kepada ketiga-tiga undang-undang yang disebutkan serta pemakaiannya ke atas orang-orang Islam dan yang bukan Islam. Konsep pembahagian harta untuk penulisan ini akan menjurus kepada pembahagian harta sepencarian di dalam kes pembubaran perkahwinan di bawah seksyen 51 Akta Membaharui Undang-Undang (Perkahwinan dan Perceraian) 1976. Selari dengan itu pendekatan undang-undang yang diaplikasikan di mahkamah sivil dan mahkamah syariah berkaitan pembahagian harta sepencarian di Malaysia akan diperjelaskan. 


\section{KONSEP HARTA SEPENCARIAN}

Secara asasnya, harta sepencarian merupakan harta yang diperolehi sepanjang tempoh perkahwinan (inter-vivos) sama ada melalui usaha bersama mahupun usaha tunggal pasangan yang berkahwin. Pelbagai definisi telah diberikan oleh para sarjana dalam mentakrifkan harta sepencarian ini. Kamus Dewan telah mendefinisikan harta sepencarian sebagai harta yang diperoleh daripada usaha suami dan isteri (Noresah Baharom et al., 2000), sementara pelbagai takrifan telah diberikan oleh para sarjana undang-undang dalam mendefinisikan harta sepencarian. Sarjana yang memberikan takrif ini termasuklah para hakim mahkamah yang mengendalikan kes-kes harta sepencarian, para ahli akademik dan sebagainya. MB Hooker yang merupakan antara sarjana terawal Barat yang menulis tentang undang-undang keluarga di Malaysia telah mentakrifkan harta sepencarian sebagai harta yang diperolehi bersama oleh suami isteri dalam masa perkahwinan (M.B. Hooker, 1976: 77).

\section{DEFINISI HARTA SEPENCARIAN}

Harta sepencarian adalah harta yang diperolehi dalam masa perkahwinan seorang suami dengan isterinya hasil dari sumber-sumber atau dari usaha mereka bersama. ${ }^{1}$ Nama-nama lain yang digunakan untuk maksud yang sama ialah carian laki bini, ${ }^{2}$ pencarian, ${ }^{3}$ gono-gina, ${ }^{4}$ hareuta sihreukat, ${ }^{5}$ Harta Suarang $^{6}$ dan lain-lain. Di Malaysia, ianya lebih dikenali dengan nama harta sepencarian atau harta syarikat. Briggs J dalam memutuskan mengenai harta sepencarian di dalam kes Hujjah Lijah bt Jamal lwn. Fatimah bt Mat Diah ${ }^{7}$ mengatakan:

“The phrase 'Harta Sepencarian', I understand to mean acquired property with the specialized meaning in this context of property acquired during the subsistence of their marriage by a husband and wife out of their resources on their joint efforts. The

\footnotetext{
Lihat kata-kata Raja Azlan Shah J dalam kes Roberts@ Kamarulzzaman lwn. Umi Kalthom (1966) 1 MLJ 163 /JH 62.

2 Dikenali dalam kalangan masyarakat Melayu Negeri Sembilan.

3 Dikenali dalam kalangan msyarakat Melayu Sarawak.

4 Dikenali dalam kalangan masyarakat Jawa.

5 Dikenali dalam kalangan masyarakat Acheh.

6 Dikenali dalam kalangan masyarakat Minangkabau.

7 Hujjah Lijah bt Jamal lwn. Fatimah bt Mat Diah (1950) MLJ 63.
} 
acquisition referred to may extend to cover mere enhancement of value by reason of cultivation or development"

Definisi yang diberikan adalah merangkumi apa-apa harta yang diperolehi semasa perkahwinan jika harta itu diperolehi secara usaha bersama dan dari sumber bersama. Ini juga termasuk jika sumbangan yang diberikan adalah hanya dalam bentuk memperkembangkan harta tersebut. Secara umumnya, harta sepencarian boleh ditakrifkan sebagai sebarang harta alih atau tidak alih yang diperoleh oleh pasangan suami isteri secara langsung atau tidak langsung dalam tempoh sesuatu perkahwinan yang sah (Mohd Norhusairi Mat Hussin, 2017: 169).

Hampir seluruh negeri di Malaysia memperuntukkan tentang harta sepencarian ini di dalam enakmen undang-undang keluarga Islam masingmasing. Seksyen 2(1), Akta Undang-Undang Keluarga Islam (Wilayah Persekutuan)1984 memperuntukkan bahawa harta sepencarian itu adalah harta yang diperolehi hasil dari usaha bersama semasa perkahwinan dan bersesuaian dengan syarat-syarat yang ditentukan di bawah Hukum Syarak. Kebanyakan enakmen negeri-negeri khususnya Enakmen Undang-Undang Keluarga Islam negeri-negeri juga telah memperuntukkan tafsiran yang hampir sama dalam undang-undang keluarga Islam masing-masing yang secara langsung telah menunjukkan pengiktirafan terhadap amalan pembahagian harta sepencarian di Malaysia (Mohd Norhusairi Mat Hussin \& Mohd Hafiz Jamaludin, 2016: 81).

Sebelum kemerdekaan undang-undang yang digunakan adalah merupakan campuran di antara undang-undang Inggeris, undang-undang adat dan undangundang Islam. Hakim dan kadi yang memutuskan mengenai harta sepencarian turut dipengaruhi dengan arus ini. Hakim Daly dalam kes Wan Nab lwn. Jasin $^{8}$ mengatakan bahawa dalam setiap kes berkaitan harta sepencarian yang dijalankan di negeri Kedah keputusan yang dibuat adalah secara teragakagak. Peranan mahkamah hanyalah sebagai satu 'guessing machine' (Salleh Buang, 1993: 152). Ini berlaku kerana tiadanya ketentuan menetapkan undangundang mana yang sebenar-benarnya terpakai dalam menentukan soal harta sepencarian. Ini boleh dilihat daripada kes-kes yang telah diputuskan.

\section{Harta Sepencarian di bawah Undang-Undang adat}

Adat Temenggung ini mendefinisikan Harta Sepencarian sebagai harta yang diperolehi oleh kedua-dua suami dan isteri semasa perkahwinan. Seandainya perkahwinan itu telah mencapai usia tiga tahun dan pasangan tersebut telah

$8 \quad$ Wan Nab lwn. Jasin, Kedah Civil Appeal No. 37 of 1342 (AD 1922). 
mempunyai anak maka harta itu termasuklah apa-apa harta yang dipunyai oleh mana-mana pihak sebelum perkahwinan mereka (Othman Ishak, 1982: 82).

Mengikut prinsip asasnya, jika terjadi suatu perceraian atau kematian manamana pihak maka kedua-dua pihak berhak mendapat bahagian di dalam harta sepencarian tersebut(dalam hal perceraian), atau pasangan yang masih hidup berhak mendapatkan harta sepencarian(dalam hal kematian). Pembahagiannya pula adalah seperti berikut:

a) Jika si suami yang menceraikan tanpa ada sebarang kesilapan di pihak isteri, si suami mestilah memberi nafkah selama 3 bulan dan semua harta perlu dibahagikan. Harta yang merupakan senjata atau alat perang di serahkan kepada suami. Dia juga akan menanggung apa-apa hutang atau cukai. Manakala semua perkakasan rumah dan tembaga akan diserahkan kepada isteri. Beliau juga akan mendapat rumah yang mereka duduki serta tanah.

b) Jika si isteri yang memohon cerai, dia hanya akan diceraikan jika dia dapat membuktikan ada tiga kesilapan di pihak suami yang menyebabkan dia ingin bercerai dari suaminya. Setelah perceraian dia haruslah mengembalikan apa-apa harta boleh alih kepada suaminya.

Menurut responden, ${ }^{9}$ undang-undang adat Temenggung ini berbeza-beza dari satu negeri ke negeri yang lain. Contohnya di Perak, apabila perceraian berlaku, seorang isteri yang telah menyumbangkan usahanya mengerjakan tanah milik pasangan tersebut, adalah berhak ke atas separuh daripada tanah yang diperolehi ketika perkahwinan. Manakala jika dia tidak memberikan apa-apa sumbangan, dia tetap akan mendapat 1/3 daripada harta sepencarian. Prinsip yang sama juga terpakai seandainya mana-mana pasangan meninggal dunia. Harta yang selebihnya akan diberikan kepada anak-anak atau ahli keluarga yang lain mengikut hukum faraidh.

Di dalam kes Teh Rasim lwn. Neman ${ }^{10}$ Plaintif dan defendan, semasa tempoh perkahwinan mereka telah memperolehi sebidang tanah daripada kerajaan negeri dan telah mengusahakan penanaman pokok getah. Empat tahun kemudian, tanah itu telah dijual dan duit yang diperoleh daripada jualan itu telah digunakan oleh defendan (suami) untuk membeli tanah lain. Plaintiff (isteri) telah mengusahakan sebahagian tanah yang dibeli oleh suaminya itu. Lapan belas tahun selepas mendirikan rumahtangga, defendan telah menceraikan plaintif. Plaintif kini menuntut satu pertiga nilai kesemua harta

\footnotetext{
$9 \quad$ Azhani Arshad (Pensyarah Kanan, Fakulti Undang-Undang, Universiti Teknologi MARA) dalam temu bual beliau bersama penulis pada 12 Januari 2016.

10 Perak Supreme court No. 232 of 1919.
} 
yang mereka miliki bersama. Mahkamah telah merujuk kes ini kepada Raja Chulan yang kemudiannya menasihatkan supaya kes ini diputuskan mengikut pendapat Majlis Diraja Sultan Perak. Berdasarkan nasihat Raja Chulan ini, Hakim Watson memutuskan bahawa plaintif (isteri) berhak mendapatkan satu pertiga bahagian harta daripada lima keping tanah yang didaftarkan di atas nama defendan. Yang pentingnya di dalam kes ini adalah ianya dibuat berasaskan prinsip undang-undang adat kerana walaupun telah dibuktikan bahawa plaintif diceraikan oleh defendan kerana melakukan zina dia tetap mendapat hak ke atas sepencarian, yang mana ini bertentangan dengan hukum syara'.

Di dalam kes Haji Ramah lwn. Alpha \& Ors ${ }^{11}$ tuntutan isteri diasaskan pada konsep upah. Dalam kes yang berlaku di Selangor ini, suami plaintif telah meninggal dunia, meninggalkan lima keping tanah sebagai harta pusaka. Selain menuntut bahagiannya berdasarkan faraid, plaintif juga telah menuntut sebahagian harta peninggalan suaminya itu berasaskan konsep upah kerana dia telah turut sama mengerjakan tanah itu. Pihak defendan yang terdiri daripada waris-waris si mati yang lain, telah menafikan dakwaan plaintif dan menyatakan bahawa plaintif tidak pernah mengerjakaan tanah tersebut. Reay JC telah memanggil seorang kadi untuk memberikan pendapat pakarnya. Di mana kadi itu mengatakan jika seorang isteri membantu suaminya menebas, menanam atau mengerjakan kebun suaminya, dia berhak mendapat upah. Oleh itu seorang balu boleh menuntut sebahagian tanah itu sebagai ganti kepada pampasan wang dan bahagian yang diberi itu boleh ditentukan mengikut budibicara mahkamah. Konsep upah ini adalah undang-undang adat yang tidak bertentangan dengan hukum Islam dan diaplikasikan dalam menentukan hak seorang isteri dalam mendapatkan harta sepencariannya. Responden ${ }^{12}$ menyatakan bahawa Islam menerima pemakaian apa-apa adat selagi ianya tidak bertentangan dengan hukum syara'.

Selain daripadaAdat Temenggung, AdatPerpatih juga turutmemperuntukkan mengenai harta sepencarian. Namun begitu, ia menggunakan prisip yang agak berbeza. Menurut adat ini harta sepencarian perlu dibahagikan mengikut prinsip berikut: 'Carian bahagi, Dapatan Tinggal, Pembawa Kembali, Suku Belah, Suarang Berageh'13

\footnotetext{
$11 \quad$ Haji Ramah lwn. Alpha \& Ors, Selangor Civil Suit No. 54 of 1924.

12 Rozlinda Abdullah (Pensyarah kanan, Fakulti Undang-Undang, Universiti Teknologi MARA) dalam temu bual beliau bersama penulis pada 20 Februari 2016.

13 Rujuk makalah, Othman Ishak: perkataan 'suarang berageh' juga dikenali sebagai 'mati laki tinggal ke bini, mati bini tinggl ke laki.'
} 
Maksudnya apa-apa harta yang diperolehi ketika berkahwin perlulah dibahagi di antara pasangan seandainya mereka bercerai. Jika mereka tiada anak dan suami mati maka harta itu akan menjadi milik isteri, prinsip yang sama juga terpakai jika isteri yang mati. Tetapi jika mereka mempunyai anak, maka pembahagian yang akan dilakukan ke atas harta tersebut perlulah dibincangkan terlebih dahulu dengan semua benefisiari.

Dalam adat ini juga harta sepencarian tidak termasuk apa-apa harta yang diperolehi oleh suami sebelum perkahwinan dan di bawa masuk ke dalam perkahwinan. Harta tersebut akan dipulangkan kepadanya semula jika bercerai dan jika mati kembali kepada sukunya. Prinsip yang sama juga diaplikasikan kepada isteri.

Pembahagiannya akan dilakukan setelah semua hutang dilangsaikan. Jumlahnya adalah sama rata diantara suami dan isteri walaupun mereka mempunyai anak ataupun isteri itu diceraikan kerana berzina. Pengecualian kepada prinsip pembahagian ini adalah jika perceraian itu adalah cerai tak'lik. Dalam hal ini maka siisteri akan mendapat keseluruhan harta sepencarian.

Selain daripada undang-undang adat, pengaruh undang-undang Islam tidak dapat dinafikan dalam membicarakan soal harta sepencarian di Tanah Melayu pada ketika itu.

\section{Harta Sepencarian di bawah Undang-Undang Islam}

Kes pertama mengenai harta sepencarian yang dilaporkan di negara ini adalah kes Tijah lwn. Mat Ali ${ }^{14}$ kes ini telah diputuskan di Pulau Pinang pada tahun 1884. Kedua-dua pihak, semasa tempoh perkahwinan mereka, telah menyewa sebidang tanah yang mereka gunakan untuk menanam padi dan tempat membuat gula nipah. Hasil jualan padi dan gula itu telah mereka gunakan sebahagiannya untuk perbelanjaan harian manakala selebihnya di simpan oleh suami. Apabila mereka bercerai, isteri telah menuntut \$50 daripada suaminya. Jumlah ini merupakan sebahagian jumlah yang disimpan oleh suami. Kadi yang dipanggil oleh mahkamah telah memberi keterangan bahawa mengikut undang-undang Islam seseorang isteri yang bercerai berhak mendapatkan separuh harta yang diusahakan bersama oleh suami isteri itu semasa mereka berkahwin.

Daripada kes ini dapat dilihat bahawa mahkamah mengiktiraf penggunaan undang-undang Islam dalam menentukan harta sepencarian. Namun begitu, kes ini telah kemudiannya diputuskan dengan menggunakan prinsip undang-

14 Tijah lwn. Mat Ali, 4 Kyshe 124. 
undang Inggeris. Ini terjadi kerana si suami merayu akan keputusan yang memihak kepada isterinya. Hakim dalam kes ini telah memutuskan rayuan pihak suami itu telah mengatakan bahawa pendapatan bersama suami dan isteri semasa tempoh perkahwinan mereka adalah milik suami seorang.

\section{Harta Syarikat}

Dalam kes Wan Mahatan lwn. Haji Abdul Samat ${ }^{15}$ Plaintif merupakan seorang isteri yang telah diceraikan dan menuntut sebahagian daripada lima keping tanah yang telah diperoleh oleh mereka berdua semasa mereka berkahwin. Defendan telah menolak tuntutan itu sambil menyatakan bahawa si isteri telah menyatakan kesanggupannya tidak membuat sebarang tuntutan terhadapnya sebagai balasan tebus talak(khulo'). Walau bagaimanapun mahkamah berpuas hati bahawa tiada sebarang bukti yang menunjukkan isteri menyatakan kesanggupan sedemikian. Apabila perbicaraan dijalankan di hadapan Pemungut Hasil Tanah, Kadi yang merasmikan upacara perceraian itu memberi keterangan bahawa mengikut undang-undang Islam, soal tebus talak tidak menyentuh harta syarikat. ${ }^{16}$ Semua harta yang telah diperoleh bersama semasa perkahwinan hendaklah dibahagi kepada dua bahagian, dan satu bahagin diberi kepada setiap pihak.

Berdasarkan prinsip ini kadi berkenaan berpendapat bahawa harta dalam kes ini ialah harta syarikat dan si isteri adalah berhak mendapatkan setengah bahagian daripadanya. Harta syarikat yang wujud di dalam undang- undang Islam adalah berasal daripada perkataan Arab yang bermaksud perkongsian.

\footnotetext{
15 Wan Mahatan lwn. Haji Abdul Samat, Ipoh Civil Appeal No. 27 of 1926.

16 Kadi Larut dalaam kes itu telah menerangkan bahawa prinsip harta syarikat adalah seperti berikut:

a) seorang itu berkahwin dan pada waktu itu dia dan isterinya tidak mempunyai harta; selepas berkahwin, dengan usaha mereka bersama, mereka memperoleh harta; harta sedemikian hendaklah dibahagi dua

b) seseorang berkahwin dan pada ketika itu sumi isteri itu tidak mempunyai harta; selepas berkahwin mereka memperoleh harta tetapi bukan dengan usaha bersama, misalnya suami berniaga manakala isteri lebih ringan kerjanya berbanding dengan suami; harta sedemikian hendaklah dibahagi tiga-dua bahagian untuk suami dan satu bahagian untuk isteri.

c) Seorang lelaki, yang bekerja dan bergaji tetap; berkahwin dengan perempuan yang tidak bekerja; isteri mengurus rumah dengan memasak, mencuci pakaian dan menjaga kebajikan suami seperti yang menjadi kelaziman di kalangan wanita Melayu masa kini, harta yang diperoleh sedemikian bukan harta bersama tetapi merupakan hak mutlak suami sahaja.
} 
Konsep asasnya adalah harta yang diperolehi ketika sesuatu perkahwinan tidak boleh dikatakan sebagai harta syarikat melainkan wujud satu perjanjian untuk memegang harta secara bersama di antara dua atau lebih orang. Menurut responden kepada kajian ini, ${ }^{17}$ apabila pihak-pihak memasuki sebuah perkahwinan maka mereka telah dikatakan membuat satu janji. Berdasarkan perjanjian inilah maka konsep harta di dalam perkahwinan itu di samakan dengan harta syarikat.

Ini boleh dirujuk di dalam kes Laton lwn. Ramah ${ }^{18}$ di dalam kes ini Mat Dawi bin Suroh(suami ) telah meninggal dunia tanpa meninggalkan sebarang wasiat. Balunya (plaintiff) telah memohon pengisytiharan mahkamah bahawa semua harta yang didaftarkan atas nama si mati semasa kematiannya ialah harta syarikat mengikut Mazhab Syafie, dan oleh itu plaintif berhak mendapatkan setengah bahagian daripadanya selain bahagiannya dalam faraid. Defendan merupakan seorang lagi balu si mati. Dan menjadi pentadbir harta pusaka si mati.

Plaintif telah mengemukakan keterangan menyatakan bahawa sebelum dia berkahwin dengan si mati, dia telah terlebih dahulu berkahwin dengan lelaki lain dan ketika berkahwin dengan si mati dia telah pun mempunyai banyak harta di Beranang, Selangor. Harta tanah di Beranang itu telah dijual dan hasilnya mereka telah membeli tanah di Tanjung Malim. Apabila tanah di Tanjung Malim itu dijual kemudiannya, mereka telah mendapat hasil yang lumayan. Hasil itulah yang telah digunakan untuk membeli tanah yang dipertikaikan sekarang ini. Gompertz HB telah memanggil Kadi Ulu Langat untuk memberikan keterangan. Kadi tersebut telah memetik Firman Allah s.w.t melalui Ayat 4 surah An Nisa, dan mengatakan bahawa harta tersebut adalah harta syarikat di dalam Islam. Dari itu ianya juga adalah harta sepencarian yang perlu dibahagikan mengikut kadar yang telah ditetapkan.

Di dalam kes Re Noorijah ${ }^{19}$ di mana si mati ialah isteri pemohon yang bernama Ismail, seorang kakitangan kerajaan. Semasa mereka mula berkahwin si mati tidak mempunyai hartanya sendiri. Setelah berkahwin, mereka telah membeli tanah yang kemudiannya mereka jual dan daripada hasil jualan itu mereka membeli tanah-tanah lain. Harta tersebut didaftarkan atas nama si mati kerana peraturan kerajaan tidak membenarkan suami memiliki apa-apa harta tanah. Selepas lapan belas tahun berkahwin, isteri telah meninggal dunia dan

17 Rozlinda Abdullah (Pensyarah Kanan, Fakulti Undang-Undang, Universiti Teknologi MARA) dalam temu bual beliau bersama penulis pada 20 Februari 2016.

18 Laton lwn. Ramah, Selangor Civil Suit No. 323 of 1926.

19 Re Noorijah, Selangor Civil Appeal no. 44 of 1934. 
meninggalkan sebelas keping tanah. Mereka tidak mendapat anak daripada perkahwinan itu. Suami telah menuntut semua harta peninggalan si mati sebagai haknya seorang. Alasan yang dikemukakan adalah harta berkenaan telah dibeli olehnya seorang diri, manakala si mati tidak memberi sebarang sumbangan atau usaha selain kerja memasak dan mengemas di rumah. Pemungut hasil tanah telah memutuskan bahawa kerja rumah yang dijalankan oleh si mati itu adalah sumbangan yang bernilai dan mengikut undang-undang Islam dia berhak mendapatkan sesuku bahagian harta itu sebagai bayaran kepada kerja atau usaha itu. Thomas HB yang kemudiannya telah merujuk kepada fatwa ${ }^{20}$ Majlis Diraja Selangor mengatakan bahawa harta peninggalan si mati itu adalah menjadi hak suaminya seorang dan tidak boleh difaraidkan.

Dapat dilihat dari kes ini bahawa konsep upah di atas usaha tenaga yang dicurahkan diiktiraf di dalam Islam. Namun begitu, ianya berjaya disangkal dengan menggunakan fatwa yang merupakan salah satu cara dibenarkan syarak. Menurut responden ${ }^{21}$ sesuatu fatwa itu tidaklah bersifat mengikat melainkan ianya dikanunkan di dalam mana-mana enakmen negeri. Di dalam kes ini hakim syariah memilih untuk mengikut fatwa yang telah diputuskan di negeri Selangor.

Kes Hajah Lijah lwn. Fatimah ${ }^{22}$ Kes ini telah diputuskan di Kelantan di mana seorang lelaki telah mewarisi sebidang tanah sebagai harta pusaka peninggalan ibu bapanya sebelum dia berkahwin dengan plaintif (isteri). Semasa mereka mula berkahwin, plaintif tidak mempunyai harta. Keduadua mereka telah sama-sama mengerjakan tanah itu dan daripada hasil yang mereka peroleh serta wang simpanan yang ada, mereka telah membeli harta tanah yang lain. Apabila suami meninggal dunia, plaintif telah menuntut sebahagian harta peninggalan suami. Mahkamah memutuskan bahawa plaintif berhak mendapat sebahagian daripada harta peninggalan suaminya.

20 Suami telah merayu di hadapan Thomas HB, kedua-du pihak kemudiannya bermuafakat merujuk kepada majlis Diraja Negeri Selangor. Jawatankusa Adat dan Agama Majlis Diraja ini kemudiannya menfatwakan bahawa:

"Jika terdapat keterangan yang cukup yang menunjukkan bahawa tanah yang didaftarkan atas nama si mati itu tidak diberi kepadanya sebagai hadiah oleh suainya, dia hendaklah diputuskan sebagai milik suami seorang dan tidak boleh dianggap sebagai harta pusaka si mati."

21 Azhani Arshad (Pensyarah Kanan, Fakulti Undang-Undang, Universiti Teknologi MARA) dalam temu bual beliau bersama penulis pada 12 Januari 2016.

22 Hajah Lijah lwn. Fatimah (1950) 16 MLJ 63. 
Berdasarkan temu bual bersama responden, ${ }^{23}$ apa yang dapat dikatakan di sini adalah hakim-hakim yang memutuskan kes-kes sebelum kemerdekaan lebih cenderung mengikut apa yang telah ditetapkan oleh hukum syarak. Walaupun mereka bukan beragama Islam ini tidak menjadi satu kesukaran bagi mereka kerana mereka seringkali merujuk kepada pendapat para kadhi yang pakar dalam hal perundangan Islam. Secara ringkasnya undang-undang Islam menetapkan bahawa jika terdapat keterangan yang menunjukkan bahawa harta itu diperolehi selepas perkahwinan dan ada usaha di pihak masing-masing terhadap usaha itu maka ia akan menjadi harta syarikat yang mana berhak dibahagikan di antara mereka seandainya berlaku perceraian.

\section{ZAMAN SELEPAS KEMERDEKAAN}

Masyarakat majmuk adalah antara kesan peninggalan penjajahan di negara kita ini. Masyarakat majmuk ini terdiri daripada tiga komponen bangsa yang besar iaitu Melayu, Cina dan India serta minoriti bangsa-bangsa lain. Begitu juga dengan anutan agama yang diamalkan di Malaysia. Bagi memudahkan pemahaman penulis akan membahagikan perbincangan ini kepada, panduanpanduan yang digunakan oleh hakim-hakim di Malaysia dalam memutuskan soal harta sepencarian dalam kalangan orang Islam dan yang bukan Islam.

\section{Harta Sepencarian dalam Kalangan Orang Islam}

Selepas kemerdekaan undang-undang harta sepencarian menjadi lebih teratur dan mantap. Apa yang agak mengelirukan adalah bidangkuasa mahkamah yang boleh mengendalikan soal harta sepencarian orang-orang Islam. Walaupun sejak tahun 70-an banyak kes diputuskan di Mahkamah Syariah (Salleh Buang, 1993: 161) masih ada kes yang diputuskan di Mahkamah Tinggi Sivil ${ }^{24}$ terutamanya jika ia melibatkan harta tanah yang bernilai tinggi. Perbincangan berikut adalah berdasarkan data temu bual ${ }^{25}$ serta kajian kes. Berikut adalah antara prinsip-prinsip yang digunakan dalam menentukan pembahagian dan hak sesuatu pasangan terhadap harta sepencarian.

23 Azhani Arshad (Pensyarah Kanan, Fakulti Undang-Undang, Universiti Teknologi MARA), dalam temu bual beliau bersama penulis pada 12 Januari 2016; Rozlinda Abdullah (Pensyarah Kanan, Fakulti Undang-Undang, Universiti Teknologi MARA) dalam temu bual beliau bersama penulis pada 20 Februari 2016.

24 Bidangkuasa mahkamah Tinggi ini adalah dinyatakan di bawah seksyen 23, Court of Judicature Act 1964.

25 Azhani Arshad (Pensyarah Kanan, Fakulti Undang-Undang, Universiti Teknologi MARA) dalam temu bual beliau bersama penulis pada 12 Januari 2016. 


\section{Sumbangan kedua-dua pihak}

Misalnya kes Robert@ Kamarulzaman 1wn. Ummi Kalthom ${ }^{26}$ di dalam kes ini sepasang suami isteri telah membeli sebuah rumah di Setapak, Kuala Lumpur dengan harga RM 50 000. Plaintif(suami) telah menyumbangkan RM 40000 manakala defendan(isteri) telah menyumbangkan RM 10 000. Oleh sebab suami pada ketika itu adalah seorang kakitangan kerajaan dan tidak dibenarkan memiliki harta tanah, rumah itu telah didaftarkan di atas nama defendan.. Setelah mereka bercerai, plaintif menuntut sebahagian daripada tanah itu sebagai harta sepencarian. Defendan menolak tuntutan itu dengan mengatakan bahawa harta itu telah dihadiahkn kepadanya. Hakim Callow yang membicarakan kes ini mengatakan bahawa berdasarkan keteranganketerangan yang ada jelas menunjukkan bahawa harta itu telah diperolehi hasil sumbangan daripada kedua-dua pihak semasa perkahwinan mereka. Ini menimbulkan anggapan bahawa ianya adalah harta sepencarian. Anggapan ini walau bagaimanapun dapat di sangkal seandainya si suami dapat membuktikan bahawa rumah itu telah diperolehi dari usahanya sendiri atau oleh isteri dengan menunjukkan bahawa rumah itu telah dihadiahkan kepadanya. Defendan telah gagal membuktikan bahawa rumah itu telah dihadiahkan kepadanya semasa perkahwinan. Semasa penangguhan perbicaraan kedua-dua pihak telah bersetuju membahagikan rumah itu kepada dua secara sama rata. Hakim kemudiannya telah mengesahkan pembahagian itu.

Apa yang menarik di dalam kes ini adalah selain daripada ianya diputuskan di Mahkamah Tinggi Sivil dan bukannya di Mahkamah Syariah, ianya diputuskan mengikut hukum syarak dan keputusannya memihak kepada seorang bukan Islam yang telah memeluk Islam.

Dalam kes Overseas Investment Pte Ltd lwn. Anthony William O'Brien \& Anor $^{27}$ yang telah diputuskan di mahkamah sivil, harta yang dipertikaikan adalah beberapa perkakasan rumah yang telah dilelongkan oleh plaintif. Plaintif menuntut sebahagian daripada hasil lelongan itu berdasarkan hujah bahawa harta itu adalah harta sepencarian. Menurut Shankar J pihak-pihak adalah beragama Islam dan oleh kerana harta-harta itu diperolehi semasa perkahwinan mereka dan di atas usaha bersama mereka, maka harta itu adalah dianggap sebagai harta sepencarian. Merujuk kepada kes ini responden yang telah ditemu bual mengesahkan bahawa jika tiada keterangan nyata mengatakan bahawa harta itu adalah milik mutlak salah seorang dari mereka

\footnotetext{
26 Robert @ Kamarulzaman lwn. Ummi Kalthom [1966] MLJ 60.

27 Overseas Investment Pte Ltd lwn. Anthony William O’Brien \& Anor [1988] 3 MLJ 332.
} 
maka mengikut undang-undang adat (yang telah diiktiraf di dalam Islam) harta tersebut adalah kepunyaan mereka berdua.

\section{Sumbangan usaha sebelah pihak ke atas harta yang diperolehi oleh pihak yang satu lagi}

Dalam kes Mohamed lwn. Commisioner of Lands \& Mines, Terengganu ${ }^{28}$ dalam kes ini harta yang dipertikaikan ialah sebidang tanah hutan seluas sembilan ekar yang diperoleh oleh suami semasa tempoh perkahwinan. Ada keterangan yang menunjukkan bahawa isteri pernah bekerja menebang, menebas dan menanam pokok getah di tanah tersebut. Setelah berkahwin selama sepuluh tahun, mereka bercerai. Isteri telah menuntut setengah daripada harta. Hakim Ismail Khan (Mahkamah Tinggi) telah meluluskan tuntutan itu berdasarkan bukti bahawa isteri pernah sama-sama mengerjakan tanah itu, oleh yang demikian tanah itu adalah harta sepencarian.

Di dalam kes Boto bt Taha lwn. Jaafar bin Muhamed ${ }^{29}$ Plaintif(isteri) bekerja sebagi pembantu di sebuah kedai kopi. Manakala defendan(suami) bekerja sebagai pemborong ikan di Dungun, Terengganu. Perniagaan suami itu kemudiannya semakin maju dan dia menggunakan hasil keuntungannya untuk membeli sebuah rumah, sebidang tanah, empat bot ikan, jaring ikan dan satu gerai menjual ikan. Keduanya kemudian dari itu telah bercerai dan sisuami hanya memberi nafkah dalam tempoh idah isterinya sahaja. Plaintif menuntut sebahagian daripada harta yang diperolehi semasa perkahwinan mereka dan sebahagian daripada pendapatan yang diperolehi daripada hartaharta yang diperolehi semasa perkahwinan mereka. Hakim Salleh Abas dalam memutuskan hal ini menyatakan bahawa harta-harta tersebut adalah harta sepencarian kecuali salah satu daripada bot yang telah didaftarkan di atas nama mereka secara bersama. Harta sepencarian itu haruslah dibahagikan mengikut jumlah 1/3 kepada pihak isteri dan 2/3 kepada pihak suami. Bot itu pula dijual dan hasilnya dibahagi sama rata di antara mereka. Alasan kepada keputusannya itu adalah kerana harta-harta itu diperolehi hasil usaha daripada suami seorang diri. Namun begitu, keterangan membuktikan bahawa si isteri telah membantu suaminya di dalam perniagaannya sama ada secara langsung atau tidak langsung.

Selepas pindaan kepada Perkara 121 Perlembagaan Persekutuan pada tahun 1988, harta sepencarian telah menjadi satu perkara yang perlu diputuskan

\footnotetext{
28 Mohamed lwn. Commisioner of Lands \& Mines, Terengganu [1968] 1 MLJ 227.

29 Boto bt Taha lwn. Jaafar bin Muhamed (1985) 2 MLJ 98.
} 
di Mahkamah Syariah. ${ }^{30}$ Dalam berbicara soal harta sepencarian, kita perlu merujuk kepada Akta yang terpakai kepada orang Islam di Malaysia bagi kita menentukan panduan-panduan yang digunakan oleh hakim-hakim dalam menyelesaikan soal harta sepencarian. Dapatan daripada temu bual secara amnya menunjukkan pembahagian harta sepencarian semasa perceraian atau kematian adalah suatu adat yang telah diterima pakai di dalam enakmenenakmen negeri di Malaysia. Ia juga telah diiktiraf oleh Mahkamah Tinggi di bawah Undang-undang Sivil (Mimi Kamariah Majid, 1999: 366).

Jadual 9 senarai II Perlembagaan Persekutuan Malaysia telah memperuntukkan kuasa bagi setiap negeri mengadakan undang-undang Islam mengenai sesebuah perkahwinan. Selaras dengan itu, terdapatberbagai enakmen dari setiap negeri yang terpakai kepada sebuah perkahwinan pasangan Islam. Peruntukkannya adalah lebih kurang sama. Apa yang membezakan adalah, di bawah seksyen mana ianya diletakkan dan perkataan yang digunakan. Untuk tujuan perbincangan ini, penulis akan merujuk kepada Akta Undang-Undang Keluarga Islam (Wilayah-Wilayah Persekutuan) 1984 (Akta 303)-selepas ini dikenali sebagai 'AUKI'.

\section{AKTAUNDANG-UNDANG KELUARGAISLAM(WILAYAH-WILAYAH PERSEKUTUAN) 1984 (AUKI)}

Di bawah seksyen $2^{31}$ 'harta sepencarian' diterjemahkan sebagai harta yang diperolehi bersama oleh suami isteri semasa perkahwinan dan berkuatkuasa mengikut syarat-syarat yang ditentukan oleh Hukum Syara'. Seksyen 122 AUKI selanjutnya mengatakan, harta yang diperolehi dalam masa perkahwinan termasuklah aset-aset yang dipunyai oleh satu pihak sebelum perkahwinan itu yang dimajukan pada sebahagian besarnya dalam masa perkahwinan itu oleh pihak yang satu lagi atau dengan usaha bersama mereka. Seterusnya di bawah bahagian V, Seksyen $122^{32}$ memperuntukkan kuasa mahkamah untuk memerintahkan pembahagian harta sepencarian.

Secara ringkasnya bolehlah dikatakan bahawa seksyen ini memberi dua keadaan di mana pembahagian harta sepencarian boleh dilakukan.

\footnotetext{
30 Rujuk Perkara 121(1A), Perlembagaan Persekutuan.

31 Akta Undang-Undang Keluarga Islam (Wilayah-Wilayah Persekutuan) 1984 (Akta 303).

32 Akta Undang-Undang Keluarga Islam (Wilayah-Wilayah Persekutuan) 1984 (Akta 303).
} 


\section{a) Harta yang diperolehi secara usaha bersama}

Jika harta yang diperolehi semasa perkahwinan mereka itu adalah hasil daripada usaha bersama mereka, maka harta tersebut boleh dibahagikan secara bentuk asalnya ataupun ianya dijual terlebih dahulu dan hasilnya dibahagi secara sama rata di antara keduanya. ${ }^{33}$ Responden mengesahkan bahawa, perintah itu boleh diberikan ketika mahkamah membenarkan lafaz talaq atau sedang membuat perintah perceraian.

Berdasarkan temu bual dan kajian kes bolehlah dirumuskan bahawa mahkamah dalam menentukan pembahagian itu hendaklah memberi perhatian kepada faktor-faktor berikut: ${ }^{34}$

i) Takat sumbangan-sumbangan yang telah dibuat oleh tiap-tiap satu pihak dalam bentuk wang, harta, atau kerja bagi memperoleh aset tersebut

ii) Hutang untuk manafaat bersama

iii) Keperluan anak-anak jika ada.

\section{b) Harta diperolehi dengan usaha tunggal satu pihak}

Dalam keadaan ini harta itu dibahagi di antara mereka dalam bentuk asal atau dijual $^{35}$ terlebih dahulu dan hasilnya dibahagi di antara mereka mengikut apaapa kadar yang difikirkannya munasabah dengan syarat pihak yang melakukan usaha tunggal itu perlu mendapat bahagian yang lebih. ${ }^{36}$ Mahkamah di dalam membuat perintah ini perlu sekali lagi memberi perhatian kepad faktor-faktor berikut:

i) Takat sumbangan-sumbangan yang telah dibuat oleh pihak yng tidak memperolehi aset itu, kepada kebajikan keluarga dengan memelihara rumahtangga atau menjaga keluarga.

ii) Keperluan anak-anak dalam perkahwinan jika ada.

Prinsip di dalam seksyen ini boleh dilihat penggunaannya di dalam kes Re Hajjah Nek Maimunah bt Salleh ${ }^{37}$ Pemohon telah berkahwin dengan si mati

33 Subseksyen (1) seksyen 58, Akta Undang-Undang Keluarga Islam (WilayahWilayah Persekutuan) 1984 (Akta 303).

34 Subseksyen (2) Akta Undang-Undang Keluarga Islam (Wilayah-Wilayah Persekutuan) 1984 (Akta 303).

35 Subseksyen (3) Akta Undang-Undang Keluarga Islam (Wilayah-Wilayah Persekutuan) 1984 (Akta 303).

36 Subseksyen (4)-proviso, Akta Undang-Undang Keluarga Islam (Wilayah-Wilayah Persekutuan) 1984 (Akta 303).

37 Re Hajjah Nek Maimunah bt Salleh [1997] 5 JS 296. 
dan tidak pernah bercerai sehinggalah kematian berlaku. Beliau merupakan seorang surirumah dan kini ingin memohon hak ke atas harta sepencarian daripada harta peninggalan suaminya. Mahkamah Tinggi Syariah negeri Terengganu telah membenarkan tuntutannnya dan mengarahkan agar 1/3 daripada harta si mati itu diserahkan kepada pemohon. Harta yang selebihnya itu adalah dibahagikan mengikut hukum faraid. Kes ini juga menjadi autoriti yang menunjukkan adat itu apabila diiktiraf dan diterima dalam agama dan perundangan ia bukan lagi merupakan semata-mata adat tetapi satu undangundang yang perlu dikuatkuasakan.

Dalam satu kes lain Noor Jahan bt Abdul Wahab lwn. Md Yusoff bin Amanshah $^{38}$ Kes ini dibicarakan di Mahkamah Kadi besar Pulau Pinang dengan menggunakan Enakmen Undang-Undang Islam Pulau Pinang 1959. Plaintif telah memberikan kesemua wang untuk membeli sebanyak 47,001 unit saham Amanah Saham Nasional. Saham itu telah didaftarkan di atas nama defendan pertama(bekas suami plaintif). Ini telah diputuskan sebagai bukan suatu harta sepencarian kerana ianya diperolehi dari sumbangan isteri sahaja tanpa ada usaha di pihak suami.

Kes Tengku Anun Zaharah lwn. Dato Dr Hussein ${ }^{39}$ menunjukkan di mana seorang suami menafikan hak bekas isterinya ke atas harta benda yang diperolehi semasa perkahwinan mereka kerana menurutnya isteri tersebut tidak memberi sebarang sumbangan dari segi kewangan atau tenaga dalam memperoleh harta tersebut. Mahkamah dalam kes ini telah mengiktiraf sokongan moral yang diberikan oleh pihak isteri sebagai satu sumbangan yang perlu dihargai. Sokongan moral itu telah membantu si suami mendapatkan gelaran 'Dato'. Diputuskan isteri juga berhak mendapat bahagiannya di dalam harta tersebut.

Menurut responden, bagi tuntutan harta sepencarian di Mahkamah Syariah, ia boleh dilaksanakan dalam tiga keadaan iaitu tuntutan selepas perceraian, tuntutan semasa perkahwinan dan juga tuntutan selepas kematian. Bagi tuntutan selepas perceraian, Seksyen 122 Enakmen Undang-Undang Keluarga Islam Selangor 2003 misalnya memperuntukkan bahawa mahkamah mempunyai bidang kuasa untuk memerintahkan pembahagian harta sepencarian apabila mahkamah itu membenarkan lafaz cerai atau perintah perceraian. Oleh itu, mahkamah hanya berbidangkuasa membicarakan kes harta sepencarian di mahkamah di negeri di mana perceraian berlaku dan didaftarkan. ${ }^{40}$

\footnotetext{
38 Noor Jahan bt Abdul Wahab lwn. Md Yusoff bin Amanshah [1994] 1 MLJ 156.

39 Tengku Anun Zaharah lwn. Dato Dr Hussein [1980] 3 JH 125.

40 http://syafiqe.wordpress.com/2008/03/04/harta-sepencarian-konsep-dan-amalan/ diakses pada 20 Mac 2009.
} 
Tuntutan harta sepencarian juga boleh dibuat semasa tempoh perkahwinan. Seksyen 23(10)(b) memperuntukan bahawa isteri boleh memohon perintah daripada mahkamah supaya diadakan terlebih dahulu pembahagian harta sepencarian sebelum permohonan poligami disahkan. Malah Seksyen 119(11) Enakmen Pentadbiran Agama Islam Negeri Sembilan 2003 menyebut bahawa sebelum Mahkamah mengesahkan keluar agama, satu perintah untuk membahagikan harta sepencarian hendaklah dilaksanakan. Kedua-dua peruntukan tersebut berkaitan dengan permohonan poligami dan juga keluar agama Islam.

Bagi tuntutan selepas kematian, meskipun tiada peruntukan khusus yang membolehkan mahkamah membahagikan harta sepencarian sekiranya akibat kematian, namun fatwa negeri Selangor menjelaskan bahawa jika berlaku kematian, maka pihak yang hidup boleh memohon pengisytiharan harta sepencarian sebelum harta itu menjadi harta pusaka. Jadi pihak itu perlu membuktikan bahawa sebahagian harta itu adalah harta sepencarian. Menurut responden ${ }^{41}$, bidangkuasa mahkamah syariah membuat pembahagian harta sepencarian apabila berlaku kematian boleh dirujuk kepada seksyen 46(2) (b) Akta Pentadbiran Agama Islam (Wilayah-Wilayah Persekutuan). Seksyen ini menunjukkan bahawa bidangkuasa mahkamah syariah adalah tidak terhad untuk memutuskan kes-kes berkaitan harta sepencarian hanya bagi pihakpihak yang bercerai, tetapi bidangkuasa mahkamah syariah turut termasuk penentuan harta sepencarian dalam kes melibatkan kematian.

\section{HARTA SEPENCARIAN KE ATAS ORANG BUKAN ISLAM DI MALAYSIA}

Akta yang mengawal perkahwinan pasangan bukan Islam di negara ini sejak 1hb Mac 1982 adalah Akta Undang-Undang (Perkahwinan \& Perceraian) 1976 (selepas ini dikenali sebagai LRA). Menurut seksyen 3(1 $)^{42}$ LRA, akta ini adalah terpakai kepada semua penduduk Malaysia asalkan dapat dibuktikan mereka berdomisil di Malaysia atau bermastautin di Malaysia. Namun begitu, subseksyen $(3)^{43}$ seterusnya memperuntukkan bahawa akta ini tidak boleh dipakai bagi seseorang Islam atau bagi seseorang yang berkahwin di bawah

41 Rozlinda Abdullah (Pensyarah Kanan, Fakulti Undang-Undang, Universiti Teknologi MARA) dalam temu bual beliau bersama penulis pada 20 Februari 2016.

42 Rujuk seksyen 3(1) Akta Memperbaharui Undang-Undang (Perkahwinan \& Perceraian) 1976.

43 Subseksyen (3) Akta Memperbaharui Undang-Undang (Perkahwinan \& Perceraian) 1976. 
hukum syarak. Jelasnya peruntukkan di dalam LRA ini terpakai kepada sebuah perkahwinan pasangan yang bukan beragama Islam. ${ }^{44}$ Di bawah LRA harta sepencarian adalah dirujuk sebagai aset perkahwinan. Seterusnya kita akan melihat kedudukan pasangan bukan Islam ini sebelum dan selepas LRA dikuatkuasakan.

\section{Sebelum LRA}

Walaupun Malaysia telah mencapai kemerdekaanya seleps tahun 1957, tetapi dengan adanya Akta Undang-Undang Sivil $1956^{45}$ memerlukan undangundang Inggeris dirujuk seandainya tiada undang-undang tempatan yang membincangkan sesuatu persoalan undang-undang atau perbincangannya terlalu kabur. Oleh kerana LR hanya berkuatkuasa pada tahun 1982 sebelum daripada itu mahkamah di Malaysia telah merujuk kepada statut di England khususnya Akta Wanita Bersuami 1957(disemak 1990) yang memberikan hak kepada seorang wanita memiliki, memperolehi dan melupuskan apa-apa harta seolah-olah dia seorang yang belum berkahwin atau feme sole. ${ }^{46}$ Seksyen 11 akta tersebut membenarkan pihak-pihak kepada sesebuah perkahwinan mendapatkan deklarasi mahkamah mengenai hakmilik atau possesi ke atas sesuatu aset (Mimi Kamariah Majid, 1999: 353). Hal ini dapat dilihat menerusi beberapa kes yang telah diputuskan.

Dalam kes Chin Shak Len lwn. Lin $\mathrm{Fah}^{47}$ si isteri telah menyumbang wang sebanyak RM 1200 manakala suaminya pula sebanyak RM 400 bagi membeli sebidang tanah di Kajang berserta sebuah bangunan di atasnya. Pendaftaran adalah dibuat di atas nama suami. Apabila mereka bercerai pertikaian berlaku dan pihak suami menghujahkan bahawa duit yang telah diberikan oleh isterinya itu adalah merupakan pinjaman yang telah pun dilangsaikan kepada

$44 \quad$ Subsekyen(3) ini telah dipinda buat pertama kalinya bagi membolehkan seseorang yang telah berkahwin di bawah akta ini atau disifatkan sebagi didaftarkan di bawah akta ini dan salah satu pihak telah memeluk Islam, maka pihak yang tidak memeluk Islam itu boleh menamatkan perkahwinanya yang terdahulu melalui peruntukkan s 51 dan juga membolehkan sesuatu perintah mahkamah dikenakan terhadapnya sekiranya mahkamah memutuskan sedemikian. Apa yang masih belum jelas adalah sama ada mahkamah boleh membuat suatu perintah nafkah, pembahagian aset perkahwinan atau perintah penjagaan. Mungkin s 51(2) memberikan mahkamah membuaat perintah tersebut. Soalnya adakah ia mengikat pihak yang beragama Islam? Lihat kes Tan Sung Mooi lwn. Too Miew Kim (1994) 3 MLJ 117.

45 Seksyen 3.

46 Seksyen 4(a).

47 Chin Shak Len lwn. Lin Fah [1962] MLJ 418. 
isterinya. Mahkamah dalam memutuskan bahawa wang yang telah diberikan oleh isteri itu bukanlah pinjaman. Konsep 'resulting Trust' yang digunakan di England telah diaplikasikan di sini. Hakim mengatakan apabila terdapat gabungan dalam mendapatkan sesuatu aset tetapi aset itu hanya didaftarkan menggunakan nama salah seorang sahaja, maka timbul anggapan bahawa aset itu dipegang sebagai suatu jenis amanah bagi pihak yang satu lagi.

Manakala dalam kes Nagapushani lwn. Nesaratnam \& Anor ${ }^{48}$ di mana seorang isteri telah menuntut haknya ke atas sebidang tanah. Tanah itu telah diberikan hak kepadanya oleh si suami. Atas dasar kasih sayang ia diberikan semula kepada suaminya di mana suami itu telah memberikan kepada ibunya. Sebuah rumah telah dibina di atas tanah tersebut dan plaintiflah yang sentiasa mengutip sewa daripada penyewa rumah tersebut. Kemudiannya suami telah membuka satu akaun di atas nama isteri dan dari masa ke semasa dia (suami) mendepositkan duit ke dalam akaun tersebut. Isteri telah mengeluarkan keseluruhan duit dan diserahkan kepada suami untuk membeli sekeping tanah yang mana ansuran tanah dibayar oleh suami. Apabila mereka bercerai, pertikaian timbul menentukan hak ke atas harta tersebut. Apa yang telah diputuskan oleh hakim di Mahkamah Tinggi adalah, mengikut prinsip Inggeris jika seseorang membeli atau membuat sesuatu perkara atau harta tetapi diletakkan di atas nama seseorang yang lain maka timbul anggapan bahawa ianya merupakan sutu hadiah kepad pihak lain itu. Anggapan ini boleh disangkal jika pihak lain itu mengatakan sebaliknya sama ada secara lisan atau tindakan. Dari sini keterangan menunjukkan apabila isteri memberi semula hak ke atas tanah itu kepada suaminya, dia memulangkan semula hadiah itu, oleh itu dia tiada hak ke atas tanah itu, manakala hak ke atas wang di dalam akaun itu perlu dibahagikan secara sama rata di antara mereka.

\section{Aset Perkahwinan di Bawah Akta Memperbaharui Undang-Undang (Perkahwinan Dan Perceraian) 1976}

Akta yang telah berkuatkuasa pada 1 Mac 1982 ini adalah dikatakan telah secara amnya mengikut prinsip yang dinyatakan di bawah seksyen 37 'English Matrimonial Proceedings and Property Act 1970'. Ianya berasal daripada cadangan $^{49}$ dari Suruhanjaya Di Raja Undang-Undang perkahwinan dan perceraian orang-orang bukan Islam (B.C. Crown, 1988: 34).

\footnotetext{
48 Nagapushani lwn. Nesaratnam \& Anor [1970] 2 MLJ 8.

49 Suruhanjaya ini mencadangkan agar mahkamah diberi kuasa untuk memerintahkan pembahagian harta yang diperolehi oleh pihak-pihak ketika perkahwinan melalui usaha mutlak salah satu pihak setelah mengambil kira sumbangan pihak yang satu lagi dalam menjaga kebajikan keluarga tersebut. Hasilnya LRA telah diluluskan.
} 
Seksyen yang berkaitan dengan pembahagian harta di dalam perkahwinan adalah seksyen $76^{50}$ LRA. Merujuk kepada peruntukkan seksyen ini, responden mengulas bahawa apa yang diperuntukkan adalah bersamaan dengan peruntukkan seksyen 122 AUKI yang telah diterangkan sebentar tadi. Oleh itu kita rujuk pemakaiannya di dalam kes-kes yang diputuskan Tan Sung Mooi lwn. Too Miew Kim ${ }^{51}$ pempetisyen dan responden telah berkahwin di bawah adat cina dan telah bersekedudukan sehinggalah mereka bercerai. Isunya di sini adalah berkaitan bidangkuasa. Ianya penting kerana tiada kedudukan yang dapat dijadikan sandaran bagi memutuskan hal harta sepencarian seseorang yang telah berkahwin di bawah LRA tetapi kemudiannya menganut agama Islam. Mahkamah manakah yang mempunyai bidangkuasa. Mahkamah Agong dalam kes ini menyatakan bahawa mahkamah tinggi mempunyai bidangkuasa. Berdasarkan temu bual dan kajian kes, dapat disimpulkan bahawa terdapat beberapa panduan yang digunakan oleh hakim untuk menentukan pembahagian aset perkahwinan. Panduan itu adalah seperti berikut:

\section{Harta diperolehi oleh usaha satu pihak}

Dalam kes Lee Yu Lan lwn. Lim Thain Chye ${ }^{52}$ seorang isteri yang menuntut hak ke atas harta yang diperolehi semasa perkahwinan mengatakan dia telah memberikan sumbangan dari segi menjaga anak-anak kepada perkahwinan itu, tugas-tugas lain yang dilakukan oleh seorang isteri. Hakim memutuskan bahawa hasil jualan harta yang dipertikaikan itu si isteri berhak mendapat $1 / 3$ setelah ditolak hutang.

Mohamed Dzaiddin J juga telah memberikan keputusan yang hampir sama di dalam kes Re Heng Peng Hoo \& Anor ${ }^{53}$ usaha seorang isteri telah diberi penghargaan, tetapi di dalam kes ini hakim telah mengambil kira perkara lain di mana harta itu merupakan satu-satu harta yang mampu dimiliki oleh suami, dia yang membuat segala bayaran, hak penjagaan anak juga diserahkan kepadanya manakala pihak isteri telah mempunyai harta yang banyak. Daripada itu hanya sejumlah bayaran sahaja perlu dibuat oleh suami kepada isterinya.

Di dalam kes B Ravindran s/o Balan lwn. Mliga d/o Mani Pillai, ${ }^{54}$ sebuah rumah dipertikaikan sebagai satu harta dalam perkahwinan. Si isteri meminta rumah tersebut didaftarkan di atas namanya. Ini adalah kerana beliau telah

\footnotetext{
50 Rujuk seksyen 76 LRA

51 Tan Sung Mooi lwn. Too Miew Kim [1994] 3 MLJ 117.

$52 \quad$ Lee Yu Lan lwn. Lim Thain Chye [1984] 1 MLJ 56.

53 Re Heng Peng Hoo \& Anor [1989] 3 MLJ 103.

54 B Ravindran s/o Balan lwn. Mliga d/o Mani Pillai [1996] 2 MLJ 150.
} 
memberi sumbangan yang besar baik dari segi kewangan atau tenaga dalam mendapatkan harta tersebut. Hakim Haidar Mohd Noor mengiktiraf sumbangan isteri, tetapi permohonannya ditolak kerana ingin mengelakkan harta itu dijual oleh isteri kemudiannya.

\section{PEMBUBARAN PERKAHWINAN DI BAWAH SEKSYEN 51 AKTA MEMBAHARUI UNDANG-UNDANG (PERKAHWINAN DAN PERCERAIAN) 1976}

Perlembagaan Persekutuan adalah undang-undang tertinggi di negara kita. Artikel 11(1) Perlembagaan Persekutuan telah menyatakan bahawa setiap rakyat Malaysia mempunyai kebebasan untuk beragama. Ia bermakna bahawa setiap rakyat Malaysia mempunyai hak untuk menentukan agama dan mempraktikkan agama pilihannya. Undang-Undang perkahwinan adalah berlainan mengikut agama yang dianuti. Bagi orang Islam, Undang-Undang Keluarga Islam di setiap negeri perlu menjadi rujukan.Manakala bagi mereka yang menganuti agama lain Undang-Undang Membaharui (Perkahwinan dan Perceraian) 1976 menjadi sumber rujukan.

Di bawah Seksyen 3(3) Akta di atas menyatakan bahawa Akta ini hanya terpakai bagi mereka yang bukan Islam sahaja. Oleh kerana peruntukan ini orang Islam adalah tidak tertakluk di bawah Akta ini dan sekaligus hak bagi pihak yang telah memeluk Islam itu gugur untuk menggunapakai seksyen 51 bagi tujuan membubarkan perkahwinan mereka. Responden menyatakan bahawa peruntukan seksyen 51 itu sendiri menetapkan atau memberi hak hanya pihak yang tidak memeluk agama Islam yang boleh memohon pembubaran perkahwinan di bawah seksyen ini. Maka terpulanglah kepada pasangannya yang masih kekal menganut agama asal sama ada mahu mengikut pasangannya menukar agama dan meneruskan perkahwinan mengikut undangundang Syariah atau memohon untuk membubarkan perkahwinan tersebut. Seandainya dia(pihak bukan Islam) tidak memohon kepada pihak mahkamah untuk membubarkan perkahwinan selepas tiga bulan daripada salah satu pasangan menganut agama Islam, maka, perkahwinan itu masih sah mengikut akta ini dan pihak bukan Islam kepada perkahwinan itu masih berhak mendapat haknya sebagai suami mahupun isteri.

Perlu dinyatakan di sini bahawa penukaran agama tidak dengan secara sendirinya atau automatik membubarkan sesuatu perkahwinan. Sesuatu pembubaran haruslah dipohon di Mahkamah Sivil. Di dalam kes Pedley v Majlis Agama Islam Pulau Pinang and Anor (1990) 2 MLJ 307 Mahkamah Syariah memutuskan bahawa apabila pasangan yang berkahwin di bawah LRA, tetapi kemudiannya salah seorang memuluk agama Islam, perceraian 
perlulah dibuat di Mahkamah Sivil. Jika dilihat Seksyen 51, ia juga hanyalah bagi situasi di mana salah seorang di dalam perkahwinan telah memeluk agama Islam. Menurut responden, di dalam kes di mana sebagai contohnya terdapat perkahwinan mengikut agama Hindu dan kemudiannya suami atau isteri memeluk agama Buddha, Seksyen 51 tidak boleh digunakan sebagai alasan pembubaran.

Apabila Mahkamah Sivil telah membubarkan sesuatu perkahwinan tersebut, maka mahkamah boleh membuat peruntukan terhadap suami atau isteri dan juga hak-hak yang berkaitan dengan anak-anak. Mahkamah juga boleh meletakkan syarat-syarat ke atas hak yang diberi. Ini boleh dilihat dalam kes Shamala a/p Sathiyaseelan vs Dr. Jeyaganesh al/1 C. Mogarajah (2004) 2 CLJ 416 dan kes Chang Ah Mee v Jabatan Hal Ehwal Agama Islam, Majlis Ugama Islam Sabah \& Ors [2003] 5 MLJ 106. ${ }^{55}$

\section{PEMBUBARAN PERKAHWINAN DI BAWAH AKTA UNDANG- UNDANG KELUARGA ISLAM (WILAYAH-WILAYAH PERSEKUTUAN) 1984}

Mengikut hukum syarak, di dalam suatu perkahwinan, jika satu pihak memeluk agama Islam manakala pasangannya kekal menganut agama bukan Islam maka perkahwinan itu adalah terbubar dengan sendirinya. Hal ini dapat dilihat berdasarkan nas al-Quran sepertimana berikut:

"dan janganlah kamu berkahwin dengan perempuan-perempuan kafir musyrik sebelum mereka beriman dan memeluk agama Islam. Sesungguhnya, wanita budak (hamba) yang mukmin lebih baik dari wanita musyrik, walaupun dia menarik hatimu. Dan janganlah kamu kahwinkan orang-orang musyrik dengan wanita-wanita mukmin sebelum mereka beriman."

(Surah al-Baqarah, 2: 221)

Prosedur yang lebih jelas telah diperincikan menurut peruntukan di dalam Minhaj al-Talibin. Walaupun undang-undang Islam di Malaysia dikatakan tidakmempunyai roh Islam yang sebenarnya, namun di dalam hal ini undangundang keluarga Islam Malaysia telah memperuntukkan mengenai pembubaran

\footnotetext{
55 Mahkamah di dalam kes-kes ini telah memutuskan bahawa membenarkan salah seorang ibu bapa menentukan agama anutan seorang anak, adalah bertentangan dengan hak yang diberikan di bawah seksyen 5 Akta Penjagaan Kanak-Kanak 1961. Walau bagaimanapun, kes Shamala telah menjadikan satu keputusan yang belum pasti berkaitan hal ini.
} 
perkahwinan sedemikian selari dengan hukum Allah SWT. Namun begitu, amalan di Malaysia adalah pembubaran perkahwinan di bawah hal ini akan hanya berlaku dengan pengesahan daripada mahkamah syariah. Seksyen 46(2), Akta Undang-Undang Keluarga Islam (Wilayah-Wilayah Persekutuan) 1984 memperuntukkan:

\section{"Jika salah satu pihak kepada suatu perkahwinan bukan Islam memeluk agama Islam, maka perbuatan yang demikian tidak boleh dengan sendirinya berkuatkuasa membubarkan perkahwinan itu melainkan dan sehingga disahkan sedemikian oleh mahkamah."}

Ternyata apa yang diperuntukkan di dalam Akta Memperbaharui UndangUndang (Perkahwinan dan Perceraian) 1976 adalah tidak selari dengan peruntukan Syariah Islam. Walaupun kedua-duanya memerlukan pengesahan pihak mahkamah dalam membubarkan perkahwinan, tetapi kuatkuasa undangundang perkahwinan sivil yang tidak terpakai kepada pihak yang telah memeluk Islam membuatkan perkahwinan itu kadangkala menjadi perkahwinan yang tidak pasti statusnya. Responden bersetuju bahawa perbezaan inilah yang menjadi punca kepada timbulnya konflik-konflik bersangkutan hak pasangan kepada perkahwinan itu semasa atau selepas perkahwinan itu dibubarkan. Namun begitu, penulisan ini akan hanya membincangkan masalah bersangkutan harta sepencarian.

Dapatlah dirumuskan di sini bahawa tuntutan harta sepencarian dalam kes seperti ini boleh dibuat selepas pasangan yang tidak menganut agama Islam itu memohon kepada mahkamah sivil untuk membubarkan perkahwinan. Tuntutan membubarkan perkahwinan ini hanya boleh dibuat selepas tempoh tiga bulan dari tarikh pasangannya menukar agama kepada agama Islam. Tuntutan harta sepencarian itu pula hanya boleh dibuat di mahkamah sivil, memandangkan perkahwinan ini telah didaftarkan di bawah satu perkahwinan sivil. Seperti yang dinyatakan di atas, seandainya pasangan yang tidak menganut agama Islam itu tidak memohon untuk membubarkan perkahwinan itu, maka mereka masih kekal sebagai pasangan di bawah satu perkahwinan sivil. Tanggungjawab pasangan yang telah menganut agama Islam itu masih kekal untuk memberi nafkah kepada isteri dan anak-anaknya. Ini berikutan perjanjian yang telah pasangan ini meterai ketika mereka dikahwinkan. Maka pasangan yang telah menganut agama Islam itu tidak boleh menuntut pembahagian harta sepencarian di mahkamah syariah walaupun beliau telah memohon kepada mahkamah syariah di bawah seksyen 46(2) Akta UndangUndang Keluarga Islam (Wilayah-Wilayah Persekutuan) 1984 bagi pasangan di Wilayah Persekutuan Labuan dan Kuala Lumpur untuk mengesahkan pembubaran perkahwinan ini. 


\section{KESIMPULAN}

Prinsip-prinsip yang akan dipertimbangkan oleh mahkamah sivil ataupun mahkamah syariah dalam mementukan pembahagian harta perkahwinan atau harta sepencarian pada asasnya adalah sama. Namun begitu, ia masih tidak menyelesaikan konflik berkaitan pertukaran agama ini. Harta sepencarian hanya boleh dibahagikan selepas perceraian atau pembubaran perkahwinan. Oleh yang demikian, dalam kes pasangan yang asalanya tidak beragama Islam yang kemudiannya satu pasangan memeluk agama Islam tanpa diikuti oleh pasangannya, prinsip pembubaran di bawah seksyen 51 Akta Memperbaharui (Perkahwinan dan Perceraian) 1976 dilihat lebih mengatasi daripada pembubaran di bawah seksyen 46(2) Akta Undang-Undang Keluarga Islam (Wilayah-Wilayah Persekutuan) 1946. Maka dapatlah disimpulkan bahawa bergantunglah kepada pasangan yang masih kekal beragama bukan Islam mempetisyenkan pembubaran perkawinan di mahkamah sivil sebelum isu harta sepencarian boleh diselesaikan.

Walau bagaimanapun, keadaan adalah berbeza selepas Parlimen meluluskan pindaan terhadap Seksyen 51 Akta Memperbaharui (Perkahwinan \& Perceraian) 1976 yang memperuntukkan mana-mana pihak boleh membuat permohonan pembubaran perceraian apabila satu pihak memeluk agama Islam. Pembubaran perkahwinan tersebut hendaklah dibuat di Mahkamah Sivil. Justeru itu jelas dengan pindaan kepada seksyen 51 ini, bidangkuasa untuk membuat pembahagian asei perkahwinan di dalam perkahwinan apabila satu pasangan memeluk agama Islam kekal di bawah bidang kuasa Mahkamah Tinggi Sivil.

Bolehlah dikatakan di sini bahawa apa yang diputuskan oleh hakim-hakim dalam menetapkan pembahagian harta sepencarian adalah pada asasnya berdasarkan prisip di bawah seksyen 76 LRA. Namun begitu, di dalam beberapa hal mahkamah menggunakan kuasa budibicara yang ada padanya untuk menyimpang sedikit dari prinsip asas. Apa yang dapat dilihat, mahkamah akan turut sama mempertimbangkan kebaikan dan keburukan pembahagian itu kepada kedua-dua pihak.

\section{RUJUKAN}

Ahmad Ibrahim (1999). Undang-Undang Keluarga Islam di Malaysia. T.p.: MLJ Sdn. Bhd.

E.N. Taylor (1937). "Malay Family Law," Journal of the Malaysian Branch of the Royal Asiatic Society, vol. xv, no. I, 37. 
M.B. Hooker (1976). Personal Laws of Malaysia. Oxford: Oxford University Press.

Mimi Kamariah Majid (1999). Family Law in Malaysia. Kuala Lumpur: Lexis Law Pub.

Mohd Norhusairi Mat Hussin \& Mohd Hafiz Jamaludin (2016). "Harta Sepencarian vs Harta Perkahwinan dalam Perundangan Sivil: Satu Sorotan Ringkas," Jurnal Al-Basirah, vol. 6, no. 1, 79-96.

Mohd Norhusairi Mat Hussin (2017). "Ulasan Harta Sepencarian Embun bin Awang lwn. Melah binti Teh dan Tiga yang lain," Jurnal Kanun, vol. 29, no. 2, 167-176.

N V Lowe \& G Douglas (1998). Family law. London: Butterworths.

Noresah Baharom et al. (2000). Kamus Dewan, ed. ke-3. Selangor: Dewan Bahasa dan Pustaka.

Othman Ishak (1982). Hubungan Antara Undang-Undang Islam dengan Undang-Undang Adat. Kuala Lumpur: Dewan Bahasa dan Pustaka.

Salleh Buang (1993). Undang-Undang Tanah di Malaysia. Kuala Lumpur: Dewan Bahasa dan Pustaka.

Shamsuddin Suhor (1994). Panduan Ringkas: Akta Memperbaharui UndangUndang (Perkahwinan dan Perceraian) 1976. Kuala Lumpur: Dewan Bahasa dan Pustaka.

\section{Senarai Statut}

Akta Undang-Undang Keluarga Islam(Wilayah-Wilayah Persekutuan) 1984

Akta Membaharui Undang-Undang (Perkahwinan \& Perceraian) 1976

Akta Penjagaan Kanak-Kanak 1961

Perlembagaan Persekutuan

\section{Senarai Kes}

B Ravindran s/o Balan lwn. Mliga d/o Mani Pillai [1996] 2 MLJ 150.

Boto bt Taha lwn. Jaafar bin Muhamed (1985) 2 MLJ 98.

Chin Shak Len lwn. Lin Fah [1962] MLJ 418.

Haji Ramah lwn. Alpha \& Ors, Selangor Civil Suit No. 54 of 1924.

Hajjah Lijah bt Jamal lwn. Fatimah bt Mat Diah (1950) MLJ 63

Laton lwn. Ramah, Selangor Civil Suit No. 323 of 1926. 
Lee Yu Lan lwn. Lim Thain Chye [1984] 1 MLJ 56.

Mohamed lwn. Commisioner of Lands \& Mines, Terengganu [1968] 1 MLJ 227.

Nagapushani lwn. Nesaratnam \& Anor [1970] 2 MLJ 8.

Noor Jahan bt Abdul Wahab lwn. Md Yusoff bin Amanshah [1994] 1 MLJ 156.

Overseas Investment Pte Ltd lwn. Anthony William O’Brien \& Anor [1988] 3 MLJ 332.

Re Hajjah Nek Maimunah bt Salleh [1997] 5 Jurnal Syariah 296.

Re Heng Peng Hoo \& Anor [1989] 3 MLJ 103.

Re Noorijah, Selangor Civil Appeal no. 44 of 1934.

Roberts@ Kamarulzzaman lwn. Umi Kalthom (1966) 1 MLJ 163 /JH 62.

Tan Sung Mooi lwn. Too Miew Kim (1994) 3 MLJ 117.

Teh Rasim lwn. Neman, Perak Supreme court No. 232 of 1919.

Tengku Anun Zaharah lwn. Dato Dr Hussein [1980] 3 JH 125.

Tijah lwn. Mat Ali, 4 Kyshe 124.

Wan Mahatan lwn. Haji Abdul Samat, Ipoh Civil Appeal No. 27 of 1926.

Wan Nab lwn. Jasin, Kedah Civil Appeal No. 37 of 1342 (AD 1922).

\section{Senarai Temu bual}

Azhani Arshad (Pensyarah Kanan, Fakulti Undang-Undang, Universiti Teknologi MARA) dalam temu bual beliau bersama penulis pada 12 Januari 2016.

Rozlinda Abdullah (Pensyarah Kanan, Fakulti Undang-Undang, Universiti Teknologi MARA) dalam temu bual beliau bersama penulis pada 20 Februari 2016. 